\title{
Comparison on the Effect of Freezing Period Between the Protein Content of Cow, Goat, Ram Meat from Tilapia and Catfish from Kaduna State, Nigeria
}

\author{
Jamila Yakasai ${ }^{1, *}$, Fatima Abubakar ${ }^{2}$, Hafsat Tukur Rumah ${ }^{3}$ \\ ${ }^{1}$ Department of Chemistry, Water Resources Institute, Kaduna, Nigeria \\ ${ }^{2}$ Department of Applied Science, Kaduna Polytechnic, Kaduna, Nigeria \\ ${ }^{3}$ Department of Chemistry, Kaduna State University, Kaduna, Nigeria \\ Email address: \\ iksh6037@gmail.com (J. Yakasai), fatimaabugus@gmail.com (F. Abubakar), rumahhafsat@kasu.edu.ng (H. T. Rumah) \\ ${ }^{*}$ Corresponding author
}

\section{To cite this article:}

Jamila Yakasai, Fatima Abubakar, Hafsat Tukur Rumah. Comparison on the Effect of Freezing Period Between the Protein Content of Cow, Goat, Ram Meat from Tilapia and Catfish from Kaduna State, Nigeria. Science Journal of Analytical Chemistry.

Vol. 8, No. 2, 2020, pp. 41-44. doi: 10.11648/j.sjac.20200802.11

Received: February 14, 2020; Accepted: February 27, 2020; Published: March 17, 2020

\begin{abstract}
This study was aimed at the evaluation of the influence of freezing on the meat/fish storage of cow, ram, goat, tilapia and catfish within a period of thirty (30) days. Samples were obtained from Kaduna North and South Local Government, Kaduna State, Nigeria. The protein content of all the meat samples were analysed using kjehdahl method and values was recorded before slaughter and the observed storage period. Among the meat category, the goat meat had the highest protein content at $46.37 \%$, while the tilapia had the highest protein content of $45.50 \%$ in the fish category. The research showed that goat meat had more protein content than all the analysed samples, followed by tilapia and ram meat had the least protein content. After the thirty (30) days freezing and storage period, the protein content of both the goat and tilapia had dropped to $38.93 \%$ and $37.62 \%$. Amongst all the samples, ram meat had the slowest protein content diminishing effect as storage period increased. The research also showed that as storage time increases via freezing, the protein content of the analysed samples also reduces with time. The protein content in all the meat and fish samples did not meet the benchmark for protein content values but were enough for consumption.
\end{abstract}

Keywords: Protein, Tilapia, Catfish, Cow, Goat, Ram

\section{Introduction}

Proteins are historically known on the idea of their individual actions as catalysts, signalling molecules, or building blocks in cells and microorganisms [1]. Protein is made from twenty-plus basic building blocks called amino acids. The twenty (20) different amino acids that the body uses to synthesize proteins are: Alanine, arginine, asparagine, aspartic acid, cysteine, glutamic acid, glutamine, glycine, histidine, isoleucine, leucine, lysine, methionine, phenylalanine, proline, serine, threonine, tryptophan, tyrosine, and valine. Nine amino acids - histidine, isoleucine, leucine, lysine, methionine, phenylalanine, threonine, tryptophan, and valine - known as the essential amino acids, must come from food [2].

Braizer, in her newsletter categorised proteinous food into three, which are Complete proteins: These foods contain all the essential amino acids. They mostly occur in animal foods, such as meat, dairy, and eggs. Incomplete proteins: These foods contain at least one essential amino acid, so there is a lack of balance in the proteins. Plant foods, such as peas, beans, and grains mostly contain incomplete protein. Complementary proteins: These refer to two or more foods containing incomplete proteins that people can combine to supply complete protein [3]. Examples include rice and beans or bread with peanut butter. Consuming adequate dietary protein is vital for maintaining best health, growth, development, and performance throughout life [4].

The Recommended Dietary Allowance (RDA) for American adults is similar to international adult protein recommendations established by the World Health 
Organization is $0.83 \mathrm{~g} / \mathrm{kg} / \mathrm{d}$ [5]. While the Institute of Medicine (IOM) established the current Dietary Reference Intakes (DRIs) for protein in 2005, including the Estimated Average Requirement (EAR), Recommended Dietary Allowance (RDA), and the Acceptable Macronutrient Distribution Range (AMDR). The EAR for protein is $0.66 \mathrm{~g}$ per $\mathrm{kg}$ body mass per day $(\mathrm{g} / \mathrm{kg} / \mathrm{d})$ and is defined as the minimum amount of protein expected to meet the individual indispensable amino acid requirements of $50 \%$ of the U.S. adult population. The RDA, however, is $0.8 \mathrm{~g} / \mathrm{kg} / \mathrm{d}$, and reflects the minimum amount of dietary protein required to meet indispensable amino acid requirements, establish nitrogen balance, and prevent muscle mass loss for nearly the entire (i.e., 97.5\%) U.S. adult population [6, 7].

Amino acids provide nitrogen, hydrocarbon skeletons, and sulphur (essential components of organisms), and cannot be replaced by any other nutrients (including carbohydrate and lipids) because neither nitrogen nor sulphur is made in the body. Amino acids are essential precursors for the synthesis of proteins, peptides, and low-molecular weight substances (e.g., glutathione, creatine, nitric oxide, dopamine, serotonin, RNA and DNA) with enormous physiological importance [8, 9].

It is reported that currently, about one billion people (including 165 million children under 5 years of age) worldwide have chronic inadequate intake of protein [10]. This however in the long term leads to protein deficiency, which indicates a lack of body protein or a relative deficiency of one or several essential amino acids. The deficiency can result from a protein-deficient diet or other events, such as diseases, and it must be distinguished from the multifactorial syndrome of kwashiorkor [11]. Very low protein intake can also lead to weak muscle tone edema (which is swelling due to fluid retention), thin and brittle hair, skin lesions, in adults, loss of muscle mass and in children, stunted growth.

Protein can either be sourced from plants or animals, making its availability prominent in the environment. Both fish and meat especially beef are excellent complete protein sources, meaning they contain all the essential amino acids [12]. With preservation techniques initiated to preserve the protein contents in plants and animal, fresh after immediate consumption. Freezing has been reported to be a more preferred technique to preserve animal protein sources for long period. It permits the preservation of flavour and the nutritional properties of foods better than storage processes. It also has the advantage of minimizing microbial or enzymatic activity. The formation of ice crystals during freezing damages the ultrastructure and concentrates the solutes in the meat, which, in turn, leads to alterations in the biochemical reactions that occur at the cellular, level and influence the physical quality parameters of the meat [13]. Also in the aspect of thawed meat, ice crystallization during freezing damages muscle integrity and results in an increase of ionic strength in the liquid water outside the crystals, possibly leading to decreased quality of the meat. For this reason, cow meat, ram meat, goat meat, tilapia and catfish were analysed for their protein content and stored in frozen form within a storage period of 30 days, to determine the protein content in each of them and also evaluate the changes in their protein content during freezing.

\section{Method of Analysis}

\subsection{Sample Collection}

Fresh cow meat, ram meat, goat meat, tilapia and catfish fish were bought at the four different major slaughtering markets (Central market, Mando fish farm, Kawo market, Barnawa fish pond) located within Kaduna metropolis in Kaduna North and Kaduna South local government areas of Kaduna State. The meat and fish samples (front, middle and rear) parts were bought in duplicates from the selected mentioned market and ponds in January; 2016. The meat and fish samples were immediately stored in an insulated freezer cooler at a temperature of $0^{\circ} \mathrm{C}$ and transported into the laboratory for immediate analysis.

\subsection{Sample Preparation}

Ten (10) fresh fish samples of catfish and tilapia each were washed with tap water several times, rinsed with distilled water and were cut into slices. They were stored in a rubber zip seal and kept in a freezer under a freezing condition throughout the duration of the research. Samples were taken each from the front, rear and the middle of each fish, cut into pieces and mixed thoroughly to obtain a homogenized representative sample. The stored homogenized fish samples were taken for analysis at day $0,3,7,10$, and 30 . The same procedures were also carried out for the meat samples as stated above.

\subsection{Method of Analysis}

The homogenised fish sample (1 g) was weighed and placed in a Kjeldahl flask; $10 \mathrm{~g}$ potassium sulphate, $0.7 \mathrm{~g}$ copper sulphate and $20 \mathrm{~cm}^{3}$ concentrated sulphuric acid were added to the sample in the Kjeldahl flask. The flask was tilted to the angle in the digester and boiled until the solution became clear. Heating continued for about 30 minutes, the flask was allowed to cool. After the samples had been cooled, $25 \mathrm{~cm}^{3}$ of sodium sulphate solution was added and stirred. Glass beads (to serve as anti-bumping granules) and $80 \mathrm{~cm}^{3}$ of $40 \%$ sodium hydroxide solution were added. The flask was then connected to the distillation unit and heated for a while. The distillate containing ammonia was collected in 50 $\mathrm{cm}^{3}$ of the indicator solution. At the end of the distillation, the receptor flask was rinsed and the solution was titrated with standard 0.1 M hydrochloric acid [14].

$$
\text { Nitrogen in sample }(\%)=100 \frac{A \times B 0.014}{C}
$$

Crude protein $(\%)=$ nitrogen in sample $\times 6.25$

Where $\mathrm{A}=$ Volume of Hydrochloric acid used in titration $\left(\mathrm{cm}^{3}\right)$,

$\mathrm{B}=$ Molarity of standard acid and $\mathrm{C}=$ Weight of sample (g) 


\section{Result and Discussions}

The protein content values of the fish and meat samples as recorded on the first day of storage after the animals had been slaughtered in Table 1 showed that the ram meat sample had a protein content value of $20.21 \%$. Cow meat sample had a protein content value of $29.75 \%$ and goat meat had $46.37 \%$. It could be seen through the result in the meat category that the goat meat had the highest protein content value, while the ram meat had the least protein content value.

Table 1. Protein Content (\%) of the Meat and Fish Samples.

\begin{tabular}{|c|c|c|c|c|c|c|c|}
\hline \multirow{2}{*}{$\mathbf{S} / \mathbf{N}$} & \multirow{2}{*}{ Samples } & \multicolumn{5}{|c|}{ Protein content $(\%)$} & \multirow{2}{*}{ Mean \pm Stdev (\%) } \\
\hline & & Day 1 & Day 3 & Day 7 & Day 10 & Day 30 & \\
\hline 1 & Ram Meat & 20.21 & 19.86 & 19.51 & 18.90 & 17.76 & $19.24 \pm 0.96$ \\
\hline 2. & Cow Meat & 29.75 & 27.73 & 26.25 & 25.00 & 22.22 & $26.19 \pm 2.83$ \\
\hline 3 & Goat Meat & 46.37 & 45.23 & 43.92 & 42.87 & 38.93 & $43.46 \pm 2.85$ \\
\hline 4 & Catfish & 32.20 & 30.62 & 29.75 & 29.40 & 27.30 & $29.85 \pm 1.79$ \\
\hline 5 & Tilapia & 45.50 & 43.57 & 42.52 & 41.12 & 37.62 & $42.06 \pm 2.95$ \\
\hline
\end{tabular}

Also in the fish category, the catfish had a protein content of $32.20 \%$, while the tilapia fish had a protein content of $45.50 \%$. This study indicates that the tilapia fish had more protein content than the catfish. The results also showed that the goat meat had the highest protein content and ram meat had the lowest. This high protein content recorded in the goat meat was also reported by Lijalem et al., (2015) whose research showed that goat meat had a protein content value of $20 \pm 1.4 \%$, cow meat had a value of $16.1 \pm 2.1 \%$ and the ram meat had a protein content value of $19 \pm 1.9 \%$. The result showed that the goat meat had the highest protein content than all sampled meat and fish protein sources. Other literatures reviewed that goat meat was actually lower in calories, saturated fats, and cholesterol than beef, pork, lamb and chicken. It also contains a higher amount of protein and more iron than beef. When compared to fish, both the tilapia and catfish had more protein content than the cow and ram meat.

Olayemi et al., reported that catfish had a protein content of $16.24 \%$, while Ofudje et al., reported that catfish had a protein content of $10.10 \%$ and $8.40 \%$, Craig Steven reported that catfish had a protein content value of $28-32 \%$, tilipia had $32-38 \%$, marine shrimp had $18-20 \%$ and the hybrid striped bass fish had a protein content value $38.42 \%$ before refrigeration and Keremah and Amakiri also reported a protein content value of $23.32 \pm 0.13 \%$ for adult catfish in Yenagoa, Nigeria. These protein content values for catfish and tilapia reported above by several researchers were however, lower than the recorded value in this study [15-18]. The high protein content observed in the tilapia and catfish samples in this research could be attributed to their feeding and environment of cultivation. Miller reported in his investigation that fishes appear to have higher protein needs than mammals and as such store large quantity of protein in its muscles as a result of the high aquaculture protein diets, been fed to it [19]. Nnadozie et al. also showed that cow meat had protein content value of $17.35 \pm 0.13 \%$, goat meat had $16.30 \pm 0.26$ and sheep meat had a protein content value of $18.98 \pm 0.13 \%$ [20]. These values were however lower than the observed protein content values for cow and goat meat in this study. George et al., attributed high content value in herbivorous animals to good quality forage, pasture and protein supplements being given to them [21]. The United State Department of Agriculture stated that for every $25 \mathrm{~g}$ of raw ram, cow and goat meat, catfish and tilapia fish that there was a $50 \%$ protein content in them. This when related to the protein content recorded in this study, it was observed that the meat and fish samples didn't meet the $50 \%$ benchmark as recommended above. It was also observed in the protein content results as shown in Table 1 that there was a significant drop in the concentration of protein content in all the fish and meat samples from day 1 - day 30. From the result, the ram meat had a protein content of $20.21 \%$ on the first day, which reduced to $17.76 \%$ on the thirty-day storage period. Cow meat reduced from $29.75 \%$ to $22.22 \%$, goat meat reduced from $46.37 \%$ to $38.93 \%$, catfish reduced from $32.20 \%$ to 27.30 and tilapia protein reduced from $45.50 \%$ to $37.62 \%$.

This gradual drop in protein content recorded in this study is in agreement with Salawu et al., protein content reduction of $60.65 \pm 2.40 \%$ for the Nile tilapia fish on the first day of storage, which reduced to $57.50 \pm 2.00 \%$ on the thirty-day storage period [22]. Similar trends were also observed by Ukenye and Kolade, reported decrease in the protein content of croaker fish from $18.72 \pm 0.18 \%$ to $17.52 \pm 0.28 \%$ from day 1 of storage to day 42 [23]. Aberoumand, also reported similar trend of protein reduction in respect to storage time with Lizadussier fish from $10.13 \%$ to $10.06 \%$, Sparidae fish from $13.02 \%$ to $12.74 \%$, Platycephaliadae fish from $10.66 \%$ to $10.59 \%$ and Sciaenide fish from $12.84 \%$ to $12.73 \%$ [24]. Investigation also proved that protein content in fishes and meat during freezing decreased with increasing duration in storage.

\section{Conclusion}

In conclusion, it was observed during the course of this research that protein content in both meat and fish samples diminished as storage period increased. This is because of protein denaturation. It is advised that meat and fish be consumed during the 10 days' storage period in order to utilize the protein content in them. 


\section{References}

[1] Jeong, H., Mason, S., Barabási, A and Oltvai, Z. N. (2001). Lethality and centrality in protein networks. Nature., 411, 4142.

[2] Harvard School of Public Health (2019). Protein. Culled from https://www.hsph.harvard.edu/nutritionsource/what-shouldyou-eat $/$ protein $/ \mathrm{html}$

[3] Brazier, Y. (2018). How much protein does a person need? Culled https://www.medicalnewstoday.com/articles/196279.php Reviewed by Katherine Marengo MD.

[4] Carbone. W and Pasiakos, S. M.(2019). Dietary Protein and Muscle Mass: Translating Science to Application and Health Benefit. Nutrients., 11 (5): 1136.

[5] World Health Organization (2007). Food and Agriculture Organization of the United Nations. United Nations University. Joint Expert Consultation on Protein and Amino Acid Requirements in Human Nutrition. WHO; Geneva, Switzerland: Protein and Amino Acid Requirements in Human Nutrition: Report of a Joint WHO/FAO/UNU Expert Consultation. (WHO Technical Report Series).

[6] Trumbo P., Schlicker S., Yates A. A and Poos, M. (2005) Dietary Reference Intakes for Energy, Carbohydrate, Fiber, Fat, Fatty Acids, Cholesterol, Protein, and Amino Acids (Macronutrients) National Academies Press; Washington, DC, USA.

[7] Wolfe R. R and Miller S. L. (2008). The recommended dietary allowance of protein: A misunderstood concept. JAMA., 299: 2891-2893.

[8] Wu, G. (2009). Amino acids: metabolism, functions, and nutrition, Amino Acids., 37, 1-17.

[9] Gabriel, A. S and Uneyama, H. (2013). Amino acid sensing in the gastrointestinal tract. Amino Acids., 45 (3): 451-461.

[10] Wu, G., Fanzo, J., Miller, D. D., Pingali, P., Post, M., Steiner, J. L and Thalacker - Mercer, A. E. (2014). Production and supply of high - quality food protein for human consumption: sustainability, challenges, and innovations. Ann. N. Y. Acad. Sci., 1321 (1): 1-19.

[11] Leitzmann, C. (2003). Encyclopedia of Food Sciences and Nutrition: Protein Deficiency. 2nd Edition. Academic Press, Pages 4864-4867.

[12] Perkins, S. (2019). Comparison Between Beef \& Fish Nutritional Content. Culled from https://www.livestrong.com/article/378459-comparisonbetween-beef-fish-nutritional-content $/ \mathrm{html}$.
[13] Leygonie, C., Hoffman, L. C and Britz, T. J. (2012). Impact of freezing and thawing on the quality of meat: Review. Meat Science., 91 (2): 93-98.

[14] Food and Agriculture Organization (FAO) (2015). Animal Production and Health Division, sources of meat. www.fao.org/meat/backgr_sources.html

[15] Ofudje, E. A., Akiode, K. O., Okon, V. E., Oduleye, O. S and Williams, D. O. (2014). Proximate and Elementary Analysis of Catfish reared in River and Pond system in Ogun State, Nigeria. actaSATECH 5 (2): 20-26.

[16] Olayemi, F. F., Adedayo, M. R., Bamishaiye, E. I. and Awagu, E. F. (2011). Proximate composition of Catfish (Clarias gariepiaus) smoked in Nigeria Stored Products Research Institutes (NSPRI): Developed Klin. International Journal of Fisheries and Aquaculture 3 (5): 96-98.

[17] Craig, S. (2009). Understanding Fish Nutrition, Feeds and Feeding. Culled from www.virginiastateuniversity.pubs.ext.vt.edu/420/420-256. Html. Posted on the 1st May, 2009.

[18] Keremah, R. I and Amakiri, G.(2013). Proximate Composition of nutrients in Fresh adult catfishes: Chrysichthys nigrodigitatus, Heterobranchus bidorsalis and Clarias gariepinus in Yenagoa, Nigeria. Greener Journal of Agricultural Science 3 (4): 291294.

[19] Miller, E. L. (2006). Protein Nutrition requirements of farmed livestock and dietary supplu; FAO corporate document repository. Culled from www.fao.org/docrep/007/ y5019e/y5019 e06.html.

[20] Nnadozie, C. U., Birin-Yauri, U. A., Muhammad, C and Umar, A. (2014). Assessment of some dairy products sold in Sokoto Metropolis, Nigeria. International Journal of Advanced Research in Chemical Science 1 (10): 31-37.

[21] George, R. M., Harper, J., Dary, J and Becchetti, T. (2017). Livestock Production. Available at www.rangelandarchive.ucdavis.edu/Annual_Rangeland_Hand book/livestockproduction.html.

[22] Salawu, S. O., Arannilewa, S. T., Sorungbe A. A and OlaSalawu, B. B. (2005). Effect of frozen period on the chemical; Microbiological and sensory Quality of frozen Tilapia fish (sarotherodan. galiaenus). African Journal of Biotechnology 4 (8): 852-855.

[23] Ukenye, E. A and Kolade, O. Y. (2015). Effect of Freezing Length on the Physical Characteristics and Nutritional Value of Croaker fresh fish. Pakistan Journal of Nutrition 14 (5): 284-286.

[24] Aberoumand, A. (2013). Impact of Freezing on Nutritional Composition of some-less known selected fresh fish in Iran. International Food Research Journal 20 (1): 345-350. 